\title{
Start-Ups, Entrepreneurial Networks and Equity Crowdfunding: A Processual
}

\section{Perspective}

\section{Ross Brown, University of St Andrews}

Suzanne Mawson, University of Stirling

Alexander Rowe, University of St Andrews

\section{Abstract}

This paper outlines findings from a large-scale interview based study of start-ups who obtained equity crowdfunding in the UK. It takes a novel integrative approach towards the analysis of entrepreneurial networks by examining both personal and business networks involved in the equity crowdfunding process. Adopting a processual perspective, the empirical findings show that networks and social capital play a critical role in the crowdfunding process. Start-ups leverage, build and draw upon a complex array of network actors and "ties" as they move through the different stages of their crowdfunding journey. The paper shows that this form of funding confers important relational benefits to recipients which amount to "more than money". It concludes that equity crowdfunding is a highly "relational" form of entrepreneurial finance, requiring holistic forms of empirical investigation. Implications for theoretical development, managerial practice and further research are outlined.

Accepted for publication in Industrial Marketing Management published by Elsevier.

Key Words

$\begin{array}{lll}\text { Entrepreneurship } & \text { Start-ups } & \text { Equity Crowdfunding } \\ \text { Social Networks } & \text { Business Networks } & \text { Entrepreneurial Networks }\end{array}$




\section{Introduction}

Stinchcombe (1965) famously noted that "new" firms have a higher propensity to fail - the so-called "liability of newnesss" - due to their lack of legitimacy, track record or effective networks. Overcoming this liability may depend heavily on an entrepreneur's ability to create effective "exchange relationships with resource providers" (Smith \& Lohrke, 2008, p.315), which explains why networks become crucial for emerging organisations such as start-ups (Aldrich et al, 1987; Katz \& Gartner, 1998; Johannisson et al. 2002; Hite, 2005).

A key resource for start-ups is finance. Due to a lack of lending track record coupled with limited collateral, start-ups often incur serious difficulties when accessing funding (Berger and Udell, 1997; Berger \& Black, 2011). Since the global financial crisis, funding difficulties facing innovative start-ups have magnified (Cowling et al., 2012; Lee and Brown, 2016), prompting them to seek out "alternative" funding sources (Block et al., 2017). While banks have traditionally dominated the funding landscape for small and medium-sized enterprises (SMEs) (Colombo \& Grilli, 2007), in recent years alternative sources of finance, including crowdfunding, have proliferated (Ahlers et al., 2015; Bruton et al., 2015; Cordova et al., 2015). ${ }^{1}$ Equity crowdfunding in particular has grown rapidly, especially in the UK, which is now Europe's largest and fastest growing market for this form of entrepreneurial finance (Nesta, 2016) largely due to early deregulation and attractive fiscal incentives put in place by the UK government (British Business Bank, 2014; Brown et al, 2015).

Crowdfunding is rooted in the broader concept of crowdsourcing (Simula \& Ahola, 2014), where the 'crowd' is collectively tapped to provide "ideas, feedback, and solutions to develop corporate activities" (Belleflamme et al., 2014, p. 586). Equity crowdfunding occurs when a large number of individuals provide small amounts of finance to businesses via online platforms and is defined as "a form of financing in which entrepreneurs make an open call to sell a specified amount of equity or bond-like shares in a company on the Internet, hoping to attract a large group of investors" (Ahlers

\footnotetext{
${ }^{1}$ While there are various forms of crowdfunding, including rewards-based, donation-based, lending-based and equity crowdfunding
} (Collins \& Pierrakis, 2012; Mollick, 2014), this paper purely focuses on equity crowdfunding. 
et al., 2015, p. 955). This form of disintermediated finance seems particularly suitable for funding early stage entrepreneurial firms (Cumming and Vismara, 2017), which tend to be insufficiently developed to attract intermediated finance such as venture capital or bank lending (Brown et al, 2015). Indeed, some claim that the use of crowdfunding may be a new form of entrepreneurial bootstrapping used by innovative resource-constrained start-ups (Bellavitis et al., 2017).

This paper examines the role of entrepreneurial networks within the crowdfunding process. In theory, equity crowdfunding should render the role of networks superfluous, as firms and investors are brought together seamlessly via third-party internet platforms. Rather than utilise personal networks of friends and family, start-ups should be able to access funding directly from anonymous investors through these online mechanisms, where personal communication is replaced with "pseudo-personal" forms of communication such as videos and social messaging (Moritiz et al., 2015). Indeed, some observers have described crowdfunding as the "disintermediation of the finance market" (Harrison, 2013, p. 286), with studies highlighting the great physical distance between crowdfunded ventures and the "people who fund them" (Agrawal et al., 2015, p. 254).

Despite this emerging view of crowdfunding as a "disintermediated" or "de-networked" process (Agrawal et al., 2015), emerging empirical research suggests that networks do in fact play a pivotal role in the crowdfunding process (Colombo et al., 2015; Frydrych et al., 2014; Mollick, 2014; Vismara, 2016) and that crowdfunding platforms themselves act as "network orchestrators" bringing together start-ups and potential investors (Ordanini et al., 2011; Löher, 2017). Indeed, these equity crowdfunding platforms act as mini online "stock markets" connecting nascent start-ups to potential investors typically outwith the reach of resource-constrained new ventures with limited networking capabilities. To date, however, there has been a lack of in-depth empirical work specifically on how new ventures use networks to succeed and optimise the opportunities offered by the crowdfunding "process". 
This paper makes an important contribution to both the emerging crowdfunding literature as well as to the social and business network literatures by exploring the changing role of various entrepreneurial networks as start-ups go through the equity crowdfunding process. Despite a considerable body of knowledge on network issues, the literature is still considered to lack "a rich understanding of when, how and why ties shift from weak to strong, social to economic, or shortterm to long-term (or vice-versa)" (Slotte-Kock \& Coviello, 2010, p. 48). To address these limitations, this paper adopts an integrative approach when assessing entrepreneurial networks, incorporating the entrepreneur's own social and business networks and how these evolve during the course of crowdfunding. Given networks "aren't static: they evolve" (Hite, 2005, p. 115), the issue of process is important because, as we will identify, raising equity crowdfunding involves distinctive temporal stages. We therefore explore the processual changes in networks during the crowdfunding process, drawing on findings from a major interview-based study of equity-crowdfunded firms in the UK.

The paper addresses a number of simple but inter-related research questions stemming from an overarching research question: what role do entrepreneurial networks play in the equity crowdfunding process? We seek to address the following specific questions: 1) What role do different types of networks play in the equity crowdfunding process for start-ups?; 2) How do networks evolve over the crowdfunding process?; and 3) What is the impact from these evolving network interactions during the crowdfunding process for start-ups? The paper is structured as follows. First, we review two relevant strands of literature on networks and crowdfunding, drawing on both social and business network theory for our conceptual framing. The methodology is then outlined before the empirical findings are presented and discussed. Finally, conclusions, managerial implications and areas for future research are addressed.

\section{Literature Review}

\subsection{Social and Business Network Theoretical Perspectives}


Broadly speaking, there are two main theoretical schools of thought in the study of entrepreneurial networks: social network (SN) and business (or industrial network) (BN) perspectives (see Table 1 below). The SN tradition is firmly rooted in the sociological literature and is often linked to the pioneering work of Granovetter (1973). The SN approach attempts to measure, often through quantitative methods such as social network analysis, the impact of an individual's network ties. According to Granovetter (1973, p. 1361), "the strength of a tie is a (probably linear) combination of the amount of time, the emotional intensity, the intimacy (mutual confiding), and the reciprocal services which characterize the tie". Granovetter's early writings focused on the role of informal ties in individuals' employment prospects, observing that weak ties with acquaintances such as an "old college friend or a former workmate" played an instrumental role in facilitating information to the "job changer" (Granovetter, 1973, p.1371). Overall, the SN literature emphasises the identification and measurement of such ties and network characteristics.

The SN perspective has been widely embraced theoretically (Leyden et al., 2014) and empirically examined (Street \& Cameron, 2007) within the wider entrepreneurship literature, where there is a continued focus on - and interest in - the role social capital plays in shaping entrepreneurship (Gedajlovic et al., 2013). For example, Kontinen and Ojala (2011) examined the internationalisation of family-owned SMEs and found that new weak network ties (often formed at international trade fairs) were crucial, whereas family ties were less important. Further empirical work in this vein showed that different types of ties promoted different types of knowledge transfer and learning between bank relationship managers and customers in Chicago (Uzzi \& Lancaster, 2003). A core criticism of the SN approach, however, is its static focus and lack of a transitive dimension to network analysis (Slotte-Kock \& Coviello, 2010). Granovetter himself noted that focusing only on tie strength ignores important issues concerning "content" and "network structure over time" (1973, p. 1378). This means that other important aspects such as the types of network ties, the relational nature of ties and the role of network ties can be overlooked. Added to this is a lack of focus on the temporality of network formation and engagement. 
The BN perspective, on the other hand, is a much more dynamic approach to studying networks and focuses on how relationships change and why such change occurs (see Table 1 below). BN researchers suggest that network development is cumulative in that relationships are "continually established, maintained and developed" (Slotte-Kock \& Coviello, 2010, p. 44). Explored by industrial marketing scholars (Håkansson \& Snehota, 1989; Mattsson, 1997; Ritter et al., 2004), interaction between parties is considered to be crucial (Freytag \& Ritter, 2005). The connectedness of a business relationship suggests that the boundary of a single such relationship can become "blurred" (Håkansson et al., 1999, p. 445), thus firms are embedded in networks "of ongoing business and nonbusiness relationships, which both enable and constrain" performance (Ritter et al., 2004 p. 175). In order to make sense of these complex temporally unfolding interconnections, researchers have typically favoured more qualitative methods, often assessing the nature of buyer-supplier relationships/networks (Håkansson et al., 1999). In this vein, scholars have shown business networks to be fundamental in terms of efficiency and development goals of large established companies like IKEA (Baraldi, 2008).

Table 1: Differing Theoretical Perspectives on Networks

\begin{tabular}{|c|c|c|}
\hline & Social Network Theory & Business Network Theory \\
\hline Antecedents & $\begin{array}{l}\text { Rooted in early sociological } \\
\text { literature by Granovettor (1973). }\end{array}$ & $\begin{array}{l}\text { Derived from the industrial marketing } \\
\text { literature on buyer-supplier } \\
\text { relationships (Håkansson \& Snehota, } \\
\text { 1989). }\end{array}$ \\
\hline Nature of Theory & $\begin{array}{l}\text { The SN perspective focuses on } \\
\text { personal networks and the } \\
\text { qualitative differences between } \\
\text { different types of ties (e.g. strong } \\
\text { and weak). }\end{array}$ & $\begin{array}{l}\text { The BN perspective is a more dynamic } \\
\text { systemic approach, focusing on how } \\
\text { networks change and why change } \\
\text { occurs. }\end{array}$ \\
\hline $\begin{array}{lr}\text { Relevance to } \\
\text { Entrepreneurship }\end{array}$ & $\begin{array}{l}\text { Extant literature within the field of } \\
\text { entrepreneurship reveals that } \\
\text { personal networks are crucial to the } \\
\text { launch of new ventures, especially } \\
\text { for alleviating informational } \\
\text { barriers. In other words, the SN } \\
\text { perspective helps us to better } \\
\text { understand the creation of start- } \\
\text { ups. }\end{array}$ & $\begin{array}{l}\text { The BN viewpoint tends to be applied } \\
\text { to growing firms. Growing firms seek } \\
\text { greater tangible resources such as } \\
\text { finance, premises and customer access. } \\
\text { To obtain these resources, } \\
\text { entrepreneurs need to tap into wider } \\
\text { and less relationally bounded } \\
\text { networks. In other words, the BN } \\
\text { perspective helps shed light on how } \\
\text { start-ups grow. }\end{array}$ \\
\hline Limitations & A core limitation of the $\mathrm{SN}$ & The BN literature often focuses on \\
\hline
\end{tabular}




\begin{tabular}{|l|l|l|}
\hline the Literature & $\begin{array}{l}\text { perspective is a lack of recognition } \\
\text { of how social network ties change } \\
\text { over time. The relational nature } \\
\text { and role of ties is often overlooked. }\end{array}$ & $\begin{array}{l}\text { established organisations and thereby } \\
\text { overlooks the initial nature of ties, } \\
\text { which help to alleviate resource } \\
\text { scarcity as firms commence trading. }\end{array}$ \\
\hline
\end{tabular}

While most researchers have typically examined networks from one or the other of these dominant perspectives, there seems merit in a combinative approach towards network analysis. While the SN approach tends to view networks as having distinctive boundaries which are mediated by the varying strength of ties, the $\mathrm{BN}$ viewpoint is more holistic and views the broader context within which inter-organisational networks exist and the external influences shaping them (Slotte-Kock \& Coviello, 2010). The BN literature, however, often focuses on established organisations and thereby overlooks the initial nature of ties addressed by the SN literature, which are critical in alleviating resource scarcity as firms commence trading.

Given the limitations identified in both approaches, there seems considerable merit in adopting an integrative use of both perspectives as advocated by some scholars (Slotte-Kock \& Coviello, 2010). Within this paper, we therefore aim to examine networks drawing on both perspectives. By integrating these under the overarching umbrella of "entrepreneurial networks", we can more effectively examine the factors mediating the performance of new ventures. Such an integrative approach enables us to assess the importance and role of different types of ties (i.e. weak versus strong), the relational nature of networks, network duration and the role of network ties in shaping organisational outcomes. By tracking how different types of networks evolve and change over time, we can also assess the complimentarity and inter-relationships between the two different types of networks.

This is especially pertinent when examining entrepreneurship, where change is often endogenous as firms' grow and networks evolve (Garnsey et al, 2006). As new ventures grow, the entrepreneur's external orientation increases to obtain external resources such as finance, sources of innovation, human capital, new customers etc. Consequently, as firms expand personal networks also expand, morphing into wider overlapping webs of multi-layered exchange relationships. In the longer run, 
the success of start-ups will depend more on the "networking activities of the whole organization than that of an individual entrepreneur" (Witt, 2004, p. 403). Within this environment, "a complex set of interdependencies gradually evolves" (Håkansson \& Snehota, 2006, p. 260) and, rather than solo entrepreneurs operating in isolation, firms become "complex adaptive systems" (Ritter et al., 2004, p. 177). Studies have found an "accumulative advantage" for well networked actors and a corresponding "liability of unconnectedness" for peripheral actors (Glückler, 2007, p. 624). In other words, inter-personal networks transition to inter-organisational networks, requiring an integrated focus combining both personal and business networks to properly ascertain how start-ups grow and evolve.

\subsection{Networking and Equity Crowdfunding}

While most empirical work in the network literature has examined access to intangible resources such as advice and information (Hoang \& Antonic, 2003), much less work has been devoted to harder resources such as finance, which is arguably one of the most critical resources for early stage businesses (Bhidé, 2003; Cassar, 2004). However the majority of research conducted suggests that networks heavily mediate access to both debt and equity finance in smaller firms (Hellmann et al., 2008; Seghers et al. 2012; Shane \& Cable; Uzzi, 1999; Uzzi \& Gillespie, 2003) and play a vital coordinative role in facilitating interactions between start-ups and funders (Shane \& Cable, 2002).

Networks seem to be particularly important within equity finance ${ }^{2}$, as this often involves close interpersonal relationships between entrepreneurs and individual investors. Unlike banks, this is a disintermediated process where relational connections are often paramount as funding "tends to come from funders who are within the network of these seeking funding" (Drover et al, 2017, p.25). In the main, the work examining entrepreneurial networks within the crowdfunding literature has adopted a strong SN perspective. During the last twenty years, a growing source of

\footnotetext{
${ }^{2}$ Equity finance occurs when an investor provides funding to a firm in return for part ownership of the company in the form of shares. Within entrepreneurial finance for small businesses, the main sources include venture capital, business angels funding and equity crowdfunding. This form of finance is typically raised by innovative and high-tech firms and such investments usually entail significant risk but offer the potential for substantial upside (Drover et al, 2017).
} 
disintermediated equity funding has been investment by "business angels" (i.e. high net worth individuals) who often invest in companies collectively through syndicates of like-mined investors (Mason \& Stark, 2004; Cumming \& Vismara, 2017). While in the past business angels had to seek out investment deals through their own personal or professional networks (Mason and Harrison, 1997), in recent years a common approach for business angels is to invest in firms directly through equity crowdfunding platforms (Wright et al., 2015). Technological advancements, such as new internet-based crowdfunding platforms, have "simplified interaction between those who want to invest money and those who need it" (Vismara, 2016, p. 587).

From a network perspective, equity crowdfunding should on paper be accessible to all start-ups, irrespective of their networks and location, due to the online nature of provision. However, informational asymmetries mean that investors in the "crowd" have limited knowledge about the legitimacy of an entrepreneurial venture (Cassar, 2004; Shane \& Cable, 2002), which is particularly pronounced in an equity crowdfunding context due to the fact that small investors also tend to have limited experience evaluating investment propositions (Ahlers et al., 2015; Cumming \& Johan, 2013; Ciuchta et al., 2016). This problem is also exacerbated by the informational opacity in most start-ups (Berger and Udell, 1998). Firms seeking this internet-mediated form of funding must therefore overcome these informational uncertainties with prospective investors through various forms of networking to allay investor uncertainty.

Indeed, the growing body of empirical work on crowdfunding strongly suggests that "networks matter" during the crowdfunding process (Colombo et al., 2015; Vismara, 2016). In the main, this research focuses on inter-personal networks and social capital. For example, research examining projects funded through the Dutch crowdfunding firm Sellaband found that initial smaller investors tend to be local friends and family because "social ties yield awareness of the opportunity to invest (and perhaps exert some social pressure to do so)" (Agrawal et al., 2015, p. 268). Similarly, research by Ordanini et al. (2011) examining three different types of crowdfunding platforms (two donation- 
based platforms and one equity-based platform) found that contributions were primarily made by the close friends of crowdfundees. Other empirical studies have also shown the number of social media connections (specifically Facebook friends) to be positively associated with the amount of capital raised through platforms such as Kickstarter in the US (Frydrych et al., 2014; Mollick, 2014) and Crowdcube and Seedrs in the UK (Vismara, 2016). One Australian study, however, using the share of non-executive directors on the firm's board as a proxy for network capital, found no connection between social capital and the success of equity crowdfunding campaigns (Ahlers et al., 2015). Overall, the bulk of this rather limited evidence base on crowdfunding suggests that SNs are capable of reducing informational asymmetries between entrepreneurs and investors.

Nevertheless, this nascent crowdfunding literature has important shortcomings. First, most empirical research has focused on rewards-based or donation-based crowdfunding (Frydrych et al., 2014; Mollick, 2014). For these campaigns, investment decisions are often predicated on the interests and intrinsic motivations of investors (Mollick, 2014). We therefore need to be aware that the drivers of investment decisions (Mortiz et al., 2015) may vary quite considerably across different platform types (Ordanini et al., 2011). The fact that investors become interwoven into the fabric of the firm as a shareholders, marks out equity crowdfunding as potentially a more relationally complex source of funding. Second, many of these quantitative studies adopt rather basic proxies for social network ties, such as the number of social media contacts on Facebook or Linkedln (see Vismara, 2016). These types of basic indicators can only reveal partial insights into the complex factors underlying relationships within crowdfunding, such as the types (strong or weak) and relational nature of ties etc. Plus, these studies primarily focus on personal rather than wider business network ties, which may also be important to aid the success of crowdfunding campaigns.

A third key weakness within this literature is the lack of a temporal dimension when analysing the crowdfunding process. There is a need to better understand the role that different networks (both $\mathrm{SN}$ and $\mathrm{BN}$ ) play throughout different temporal episodes during this process. Contrary to most 
studies, the empirical research reported in this paper attempts to unpack the distinctive temporal phases within the crowdfunding process (see Figure 1 below). This paper attempts to fill these gaps and contribute to the literature by conceptualising the equity crowdfunding process, looking specifically at the changing nature and role of different types of networks at various points along this evolutionary process.

Figure 1: Personal and Business Networks in the Crowdfunding Process: An Integrative Perspective

\begin{tabular}{|l|l|l|l|}
\hline $\begin{array}{l}\text { Before } \\
\text { What types of } \\
\text { business networks are } \\
\text { important to enable } \\
\text { start-ups to } \\
\text { commence the } \\
\text { crowdfunding } \\
\text { process? }\end{array}$ & $\begin{array}{l}\text { During } \\
\text { What role do } \\
\text { different types of } \\
\text { networks play as } \\
\text { firms undergo the } \\
\text { crowdfunding process } \\
\text { and how do these } \\
\text { evolve over time? }\end{array}$
\end{tabular}

\section{Methodology}

\subsection{Method and Data}

In line with the majority of entrepreneurship research (Suddaby et al., 2015), most research on crowdfunding has taken a quantitative approach (e.g. Belleflamme et al., 2014; Mollick et al., 2014). Scholars have called for more qualitative work on crowdfunding to better understand the nuances of this process as well as the benefits, both tangible and intangible, it confers on recipient firms (Brown et al., 2015; Frydrych et al., 2014; Moritz et al., 2015) in order to "provide deeper understanding of specific entrepreneurial activities and processes" (Frydrych et al., 2014, p. 263). Depth interviews have been found to be a particularly useful research technique when unpacking the "multifaceted, temporally unfolding situations and causal mechanisms" (Graebner et al., 2012 p. 279) within complex environments. This method has also been found to be effective in studying the complex dynamics of entrepreneurs' social (Uzzi \& Lancaster, 2003; Jack et al., 2008) and business (Andersen 
\& Medlin, 2016) networks and has been chosen as the primary method of data collection within this qualitative research design.

The study adopted a processual perspective. Process studies have a long established pedigree in social science research, with sequential patterns deemed critical for explanation (Pentland, 1999). Process research deals with "how events come into being and unfold over time in a context" and is important for understanding business networks, which are themselves "continuously re-created" (Halinen et al., 2012, p. 215). This study deployed a cross-sectional "point mapping" process, which is a retrospective study of events and stories told by respondents at a particular point in time (Halinen, 2012). This could potentially create problems in terms of the recall bias of interviewees (Michel, 2001). To mitigate this, firms needed to have completed crowdfunding within the last twelve months, so that reflections on the process were relatively recent. In many cases, less than 6 months had elapsed since completion. Whilst recall bias can be problematic, there is recognition that time to reflect on key events can be helpful, as respondents may be better able to articulate issues and events that may have been impossible to discuss during or immediately after they occurred (Greiner, 1972). Overall, our focus was on ensuring methodological quality, with methodological trustworthiness and analytical generalisation the key measures of reliability and generalisability (Healy \& Perry, 2000).

In terms of sampling, potential participants were identified purposively ${ }^{3}$ from the pool of entrepreneurial firms that had successfully completed the crowdfunding process via the three main equity platforms in the UK - Crowdcube, Seedrs and Syndicate Room ${ }^{4}$. Companies were identified from a mixture of sources such as the three platforms themselves, newspaper articles about successful campaigns and other connections in the crowdfunding community made through social media (snowball sampling). Of the 284 companies identified and initially approached via email and

\footnotetext{
${ }^{3}$ Firms were required to have completed the crowdfunding process within the 12 months preceding the start of the study. They were also required to still be trading and to remain under original ownership.

${ }^{4}$ There are a growing number of equity platforms in the UK. Together these platforms attract the majority of firms who wish to raise equity crowdfunding in the UK.
} 
telephone in January 2015, 63 agreed to participate in our study - a response rate of $22 \%$. To the best of our knowledge, this figure represents the largest qualitative study on equity crowdfunding to date and well above the norm for studies adopting qualitative methods (Saunders \& Townsend, 2016). The interviews were conducted between February and October 2015 via telephone and were on average approximately 45 minutes in length. All interviews were digitally recorded and transcribed immediately upon completion.

As more than one researcher conducted the interviews, close attention was paid to ensure that each researcher adopted the same interview protocol, with a standard interview template derived drawing on the entrepreneurial finance and networks literature. Interviews were semi-structured, with a number of open-ended questions utilized to tease out pertinent relationships between various network actors. Standard questions focused on the nature of funding used to establish the firm (e.g. friends, family and founders etc.), the rationale for seeking crowdfunding, the nature of network ties used during the initial crowdfunding campaign and the networks and benefits entrepreneurs gained from the crowdfunding process. Standardised probes for each question allowed researchers to further explore how social and business networks evolved during the entire crowdfunding process. In order to further explore the crowdfunding process itself, a small number of interviews ( $n=8)$ with crowdfunding platforms, business angels and incubators were also undertaken. Supplementary interviews with related actors are often used in qualitative research to help triangulate emerging themes from company interviews (Patton, 2002).

\subsection{Data Analysis}

The main form of data analysis utilised was a partially grounded approach associated with the Gioia methodology, one that "makes clear all relevant data-to-theory connections" (Gioia et al., 2012, p. 22). All interview transcripts were used during the coding process, which began by mapping the first order concepts elicited from the interviews. This produced a long list of theoretical concepts. Over thirty or so concepts emerged from the first phase of the coding process. By seeking similarities and 
differences among these first order concepts, a number of core second order themes emerged from the data analysis process. Often the coding involved the use of labels that were derived directly from the informant interviewees during the different phases of the crowdfunding process. These labels (e.g. "more than money" and "bringing angels to the table") are used as sub-headings within our sub-sections below to directly link the raw data to the description of the findings ${ }^{5}$. Every transcript was analysed independently by each researcher, before codes were compared and reassessed by the researchers as a group in order to ensure analytical rigour (Guba \& Lincoln, 1994). Upon consulting the networks literature, the research transitioned from an "inductive" method to an "abductive" approach (Dubois \& Gadde, 2002), whereby our data and existing theory were considered in tandem (Gioia et al., 2012).

Given the very small number of crowdfunded companies in the UK, and the high associated risk of identification, interviewees were guaranteed anonymity rather than confidentiality. While direct quotations are used to ensure transparency of collected data (Healy \& Perry, 2000), company names and crowdfunding platforms have been anonymised at the request of participants. Due to space constraints, not all interviewees were included in this paper, however the direct quotes cited come from a representative cross-section of over half the 63 companies interviewed. No more than one quote has been used from each interviewee. Where multiple quotes appear to highlight key points, these are taken from different interviewees. None of the quotes included in-text are from the triangulation interviews with platforms, business angels or incubators, however these helped to shape the overall analysis process.

\subsection{Cohort Characteristics}

With 63 firms in our sample, the cohort was, surprisingly, relatively homogeneous in terms of demographics and other characteristics (see Table 2). The vast majority of the entrepreneurs interviewed were young males aged between $25-45$, most of whom were embarking on their first

\footnotetext{
${ }^{5}$ Some of the other sub-headings were developed by the researchers during the coding process when deriving the second order themes (e.g. "building momentum").
} 
venture. The start-ups in the sample were young, on average of 3 years old; only $5 \%$ were older than 10 years of age. They were all SMEs as per the OECD definition (OECD, 2005) and most (75\%) were operating in the B2C sphere. There were very few genuinely "high tech" R\&D intensive firms (less than 5\%). The firms were spatially concentrated in the London and South East, with a handful outliers in the north of England, Cornwall and the central belt of Scotland. This is very much in line with the overall demand for equity crowdfunding, which is heavily concentrated in London and South East England (Baeck et al., 2014; British Business Bank, 2014). Overall, the cohort appeared to be in line with the general population of crowdfunded firms, based on triangulation interviews with the platforms.

Table 2. Overall sample characteristics $(n=63)$

\begin{tabular}{|l|l|}
\hline Role of respondent & Founder/entrepreneur \\
\hline Entrepreneur age & $25-45$ \\
\hline Gender ratio (male : female) & $9: 1$ \\
\hline Average venture age & 3 years \\
\hline Average venture size (employees) & $>10$ \\
\hline Most common sectors & Food and drink (30\%), digital media (20\%), clean technology (15\%) \\
\hline Average funding raised & $£ 523,857$ \\
\hline Average equity issued & $18.55 \%$ \\
\hline Average new investors & $159^{6}$ \\
\hline
\end{tabular}

\section{Findings}

As previously highlighted, the crowdfunding process was found to have three distinct phases or temporal episodes: pre-crowdfunding phase (before the official campaign launch); active crowdfunding phase (campaign launch to campaign completion); and post-crowdfunding phase (after campaign closure). This process is outlined in greater depth in Figure 2 below. The length of each phase, as well as the entire crowdfunding process, varied across sample firms, with the length of the entire process ranging from 9 days to 6 months. Empirical findings will now be detailed in relation to each of these phases.

\footnotetext{
${ }^{6}$ One firm in our sample had a considerably larger number of new investors (2,375), making it a significant outlier. Excluding this firm from
} the analysis, the average number of investors was 159 (from 216). 
Figure 2: The Equity Crowdfunding Process

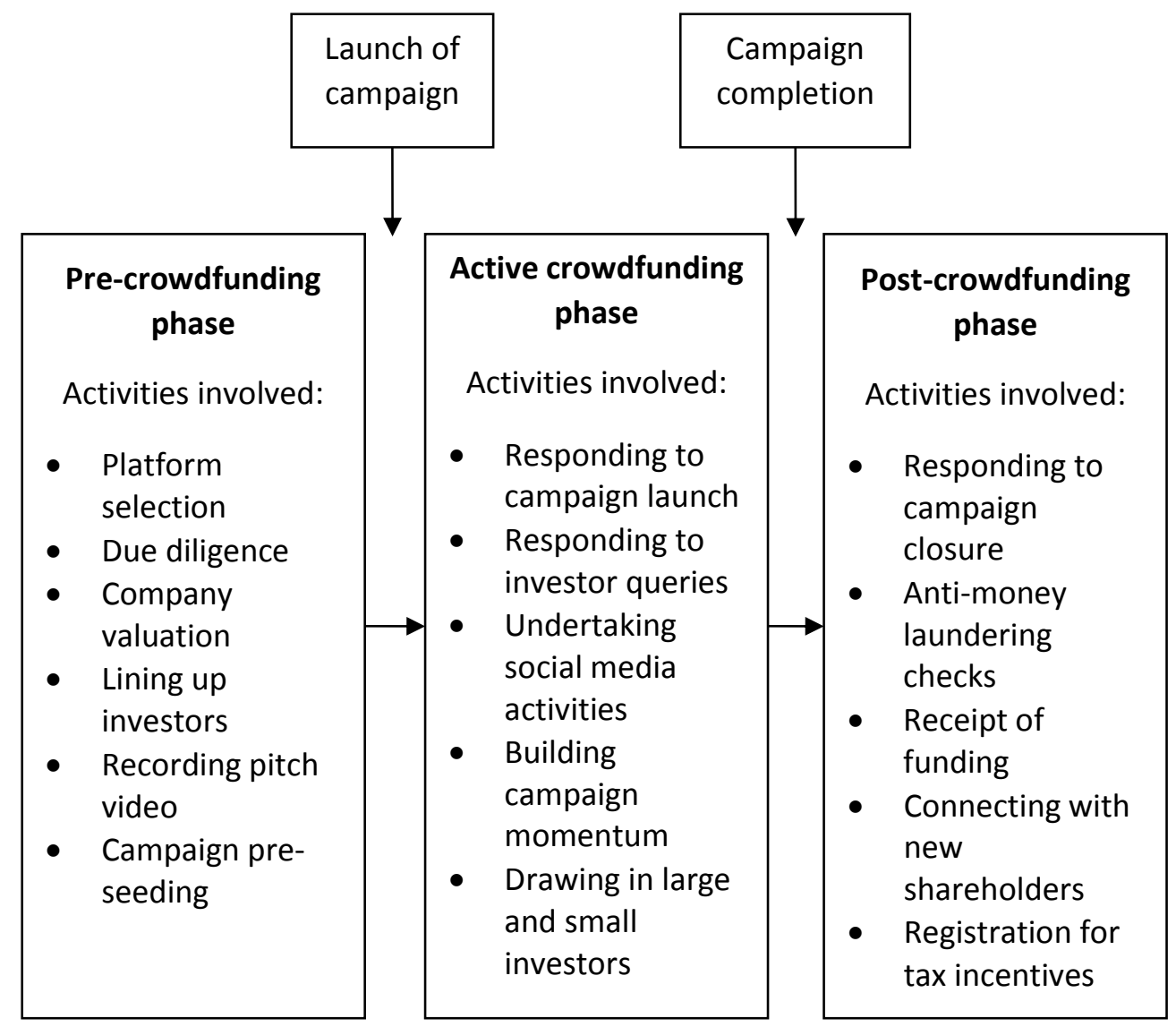

\subsection{Phase 1: Pre-crowdfunding}

\subsubsection{Strong and Weak Ties Promoting Crowdfunding}

For all the firms in our sample, the rationale for pursuing equity crowdfunding was heavily mediated by personal networks based on a mixture of strong and weak ties. Often the decision to use equity crowdfunding was due to a lack of relationships with other funders such as banks, which informed their appraisal of different options. However, the rationale for using crowdfunding often went beyond simply accessing funding. Whilst some firms came to this decision quickly, particularly if access to finance was a critical concern, the majority took some time to consider equity crowdfunding as a funding option and to evaluate how this would work for their own particular businesses. 
"We then moved to equity crowdfunding because it's so similar to what we do: it's all about a social network."

"We needed a platform that understood the sharing economy - that's our business. A platform that was social and where we could speak to a human being and where we're receiving a personalised service. I can speak to them personally."

In terms of initial awareness and consideration of crowdfunding, referral via personal networks was a critical factor for the vast majority of firms in our sample. Many entrepreneurs noted that they were encouraged to look into equity crowdfunding by friends, family and business colleagues. In some cases, the referent had personal experience with crowdfunding, but more commonly they had knowledge of crowdfunding from their own wider network. The nature of referent experience appears to have an effect on how entrepreneurs were introduced to both the concept of crowdfunding and to different platforms - entrepreneurs directed into crowdfunding via referents with first hand crowdfunding experience were less likely to have explored a variety of crowdfunding concepts and platforms, choosing to follow in the footsteps of their peers.

"In the end it was a bit of a relationship deal. There was a guy l'd met a few years ago before and he was working with [Crowdfunding Platform] and I liked what he was doing and saying so we went in that direction."

Just under half of our sample firms were involved in a business incubator or accelerator programme when they first encountered and considered crowdfunding as a possible finance option. These firms were all directed to crowdfunding by their respective programmes (i.e. weak ties), and were again heavily influenced by personal recommendations of specific platforms.

"I was talking to my finance guy [at Accelerator] - talking about the banks - he proposed the meeting with [Crowdfunding Platform] as an option for us and he knew most of the 
crowdfunders so he made an introduction. We sent over our stuff and we were put in touch with one of their guys pretty quickly."

"The access to finance part of the [Accelerator] helped me make the contacts with regards to crowdfunding at [Crowdfunding Platform]."

"We heard about [Crowdfunding Platform] through [Accelerator] - we met with the founder and said that it would work very well on their platform."

The nature of ties to various existing investors meant that the process of using crowdfunding was somewhat path dependent. This was particularly the case amongst firms who had been referred to particular platforms by their shareholders.

"[Crowdfunding Platform] were the recommended platform from our shareholders so that's just where we went."

"Our investor group who had invested in us previously had discovered [Crowdfunding Platform]. Knowing people and knowing a track record/relationship is important so we went with them."

"There was no question who we were going to talk to. Our investors knew the people at [Crowdfunding Platform]. If I had said I wanted to talk to [other Crowdfunding Platform] they would have said I was nuts!

\subsubsection{Relational Platform Interactions}

It was also noted how the overall crowdfunding ecosystem was cumulatively driving firms towards equity crowdfunding. Crowdfunding platforms are now running numerous events and, in some cases, use personal networks to contact firms who could potentially become customers. One respondent even noted that their bank, one of the UK's "big 4", was referring potential customers on to their 
preferred equity crowdfunding platform if they felt that they wouldn't meet the requirements for a business loan.

"We were interested in experimenting with crowdfunding and were introduced to [Person at Crowdfunding Platform] by both [Accelerator] and [Business Support Programme]. [Person at Crowdfunding Platform] invited us to an event they were running which was great. We are both in [City] and we know the same people. They already knew who we were and we already knew who they were."

"[Crowdfunding Platform] approached us - they had heard about us and wanted to use us as a case study. Fortunately we'd been looking into equity crowdfunding for a year or so, so the approach came at the right time."

In the run up to a campaign, entrepreneurs devoted a lot of time towards interacting with the platform itself. This was due to the platform undertaking due diligence on the veracity of the firm's business plans; it also involved entrepreneurs working with a platform to value the firm. As one entrepreneur noted, "it takes away the valuation argument in a deal". During this time entrepreneurs really valued having strong connections with the platforms, particularly as many of them were crowdfunding for the first time and required more support.

"You definitely have much better engagement than you'd ever get from a bank manager or a VC-much more of a 2 way street."

"Every single statement you make is trawled over by [Crowdfunding Platform] lawyers. They have to be backed up - very hands on. They gave us advice to seek investors beforehand to build up momentum very quickly."

\subsubsection{Pre-Seeding Through Strong Ties}


Just as platform identification and selection was heavily mediated by personal recommendation, so too were the early decisions related to setting up a crowdfunding campaign. The importance of "preseeding" crowdfunding rounds has been recognised in the literature as a critical enabler of campaign success (Agrawal et al., 2015; Ordanini et al., 2011) and each of the firms interviewed had arranged for their campaigns to be pre-seeded (on average $1 / 3$ of the campaign's value). To do this, entrepreneurs went out to their networks, predominantly friends, family and previous investors, to raise the required capital to stimulate this "herd" effect.

"Without an established network, or investors, it's incredibly difficult to raise the finance [needed to crowdfund]."

"We reached out to friends and family for initial funding. It's difficult with targets - you have to have a minimum amount and if you don't hit it then you don't get any of the cash."

"We created out own sort of crowdfunding process - we approached family, friends and an angel investor."

"We did have to raise a lot of the money ourselves. We raised $11.1 \mathrm{~m}$ ourselves with help from our friends and investors and we pre-seeded the crowdfunding round with that money. We wondered 'why don't we just look for a few more angel investors and forget this crowdfunding malarkey', but we agreed that crowdfunding had a useful purpose in pinning down the value of the business and that's what it did.

\subsubsection{Summary of Phase 1 Network Dynamics}

During this initial phase it appears entrepreneurs utilise (and generate) a mix of strong and weak ties during the crowdfunding process. These help promote the concept of this funding mechanism to the entrepreneurs. It appears that fairly weak business ties with platforms become a dominant aspect thereafter. Importantly, however, strong ties to existing family, friends and previous investors seem central to determining the success of these campaigns. 


\subsection{Phase 2: Active crowdfunding phase}

\subsubsection{Building Momentum}

During the active campaign phase, firms engaged in a different manner of looser or weak network ties. Rather than leveraging their own network for advice, support, capital etc., entrepreneurs were more focused on developing new ties and trying to further build their network by interactions with potential new investors via the crowdfunding platform. The majority of respondents noted that the nature of the online platform meant that engaging with prospective investors was far easier than traditional methods such as cold calling, with the platform helping to bring firms together with likeminded individuals.

"[Crowdfunding Platform] allows information to be quickly exchanged between parties to get people interested and ready to commit - until people commit to an idea it's just an idea."

Importantly, firms noted that whilst the online platform allowed for easier interaction with prospective investors, engaging these individuals still required time and effort. The majority of companies noted that it was time consuming to fulfil requests for business plans and further information on the company, particularly when there was no guarantee that enquiries would result in investment. There was however recognition that these interactions had the potential to lead to new network ties, even if there was no subsequent investment.

"Some [investors] would grill us - loads of questions, relevant and interesting for a week or whatever and invest 150 and some who didn't even request the business and subsequently invested thousands. You just don't know."

"We started life as an e-commerce website. We could have easily gone out to private investors to use, but the community has been so important to our business and is still so important to our brand so we wanted to give them a chance to get involved. Not everyone 
that wanted to invest could, but even getting people to hear about us and maybe buy or product in their local store is a great outcome."

\subsubsection{Bringing Angels to the Table}

In many cases, these interactions led to engagement with business angels for the first time. Business angels have been observed to be increasingly active on crowdfunding platforms (Baeck et al., 2014), and nearly two thirds of our respondents noted that they had engaged with business angels via the crowdfunding process. This was particularly important to those firms who lacked network contacts in this funding space.

"We had wanted angels but didn't have a well-developed network and couldn't have in depth conversations with any of them before [starting crowdfunding]."

"I think it opens the doors for a lot of SMEs who might not have the network in order to find private angels."

"Angels often have their own networks, but they now seem to be concentrating themselves in online equity platforms so they're easier to access."

The process of undergoing a successful campaign was viewed as a key event for many entrepreneurs in terms of the investor networks it created. Regardless of whether new ties were with business angels, other professional investors, or members of the "crowd", respondents were very clear about the desire to build a relationship with each of these individuals during the crowdfunding process that could be further developed and leveraged over time.

"It sort of validates companies because you're in the spotlight and a lot of people are looking at you, and if you succeed, then it opens all kinds of doors. People take you more seriously and the networks you can create are also very beneficial." 
"The sheer number [of new ties] is great, so we now have a database of all those people, all of whom we can reach out to."

\subsubsection{Summary of Phase 2 Network Dynamics}

During the active crowdfunding campaign phase depicted above, a newer set of network connections emerge involving two distinct relational elements. First, the start-ups engage with the wider body of small investors -the so-called "crowd"- who interact with the firms in a varied manner to assess the firm's investment potential. Second, this process also opens up business network connections to professional investors. Business angels often become alerted to the investment opportunities in these firms without any prior knowledge or relationships.

\subsection{Phase 3: Post-crowdfunding phase}

\subsubsection{More than Money}

Upon completion of the crowdfunding campaign (from the point when the campaign officially closed) crowdfunding often resulted in what can be deemed as "more than money". Although finance was a key motivational driver for some entrepreneurs, the vast majority of entrepreneurs saw equity crowdfunding as an opportunity to raise awareness and support from new individuals and looked forward to building relationships with new contacts arising from the process.

"Some of the biggest investors who came to us through [Platform] are proving to be invaluable to our business due to their skills and network - it's entirely in their best interest to help us as much as possible and increase the size of their slice of our pie!"

"The feedback from the advertising and the publicity of it were all beneficial to the company as a whole, not just the finance." 
Nearly every firm interviewed noted that one of their first actions ex post was to engage with new investors and to start the process of developing and strengthening relationships. This was considered to be a significant benefit.

“[Crowdfunding] has allowed us to become involved with investors we hadn't met before - to start building new relationships."

"For example, we've created some amazing financial models with one of our investors because financial modelling is what he does. We've also had recommendations from someone who's put us in touch with interesting people and have helped us make great contacts."

Despite the interest in engaging with new contacts and widening their networks, most of the firms perceived only small changes in the size of their networks. Despite firms gaining a rapid influx of new shareholders, some respondents felt that their networks were not substantially different and that they had "changed very little over the crowdfunding process." This may be due in part to the fact that over half of the companies interviewed had drawn heavily on existing networks to raise finance and thus not all investors were "new" ties to the business.

"The reality is, at the end of the day, the crowd as a 'group of unknown strangers' actually made up a small proportion of our funding. We really looked to the relationships we'd built over the last couple of years and leaning on them to come in and fund the business. It was a way for everybody to get on board and move forward with confidence."

"I wouldn't necessarily say that crowdfunding actively changes your network because what's great about crowdfunding is that it gives you a platform to bring on the people that you already have in your network."

"[Crowdfunding] allows you to develop and access your own network and their networks of investors." 


\subsubsection{Network Orchestration}

Interviewees were reluctant to share details of exactly how many "brand new" investors came from the crowdfunding round, but of those willing to disclose such figures the average was approximately fifteen percent. Given the comparatively small growth of networks arising from the crowdfunding process, it is understandable that respondents emphasised the importance of further building relationships with network ties, both new and old. There was widespread awareness that they would need to leverage their networks again in the near future, particularly in terms of raising subsequent rounds of finance and further developing their business.

"We are turning to another round next month. I don't really think we even need to go through [Crowdfunding Platform]. I can just write a letter to my external investors from [the last round on Crowdfunding Platform]."

It is important to note, however, that engagement with new investors was not always easy for firms, with many noting that such engagement was time consuming and took management time away from core business decisions. Difficulties managing the uplift in new stakeholders was a common observation, with many firms wondering how they would be able to maintain engagement in the longer-terms with a range of different individuals.

"There are downsides [to crowdfunding] - you can end up spending most of your time sorting the stakeholder management of the investors and this is something that concerns me going forward."

\subsubsection{Summary of Phase 3 Network Dynamics}

The findings clearly show that crowdfunding confers multiple pecuniary and non-pecuniary benefits on firms who successfully go through the process. It helps cement weak ties with new business networks such as business angel investors whilst simultaneously strengthening weak ties to small investors in the "crowd", similar to the "fanvestors" noted by others (Brown et al., 2015). The post- 
crowfunding phase also sees the start-ups become engaged in a form of "network orchestration" which has both positive and negative elements.

\section{Discussion}

We now reflect on the rich empirical findings reported. The processual qualitative methodology adopted in this study enabled us to closely examine the role of different types of networks involved in the crowdfunding process, how they evolved and what outcomes arose from these relational interactions.

\subsection{The Network Dynamics of the Crowdfunding Process}

To properly understand of the role of networks in equity crowdfunding, it is vital to distinguish between the different phases that comprise the "crowdfunding event". Under this processual perspective, which helps delineate and comprehend the rich empirical findings reported in this paper, we can see that networks undergo substantial change during the crowdfunding process. These findings reinforce the need for scholars to adopt integrative theoretical perspectives, incorporating both $\mathrm{SN}$ and $\mathrm{BN}$ viewpoints, when examining how different network ties form, adapt and reconfigure over time. Some key findings during each phase are highlighted below in Table 3 . This delineates the main theoretical inferences derived from the empirical work.

Table 3. The nature of networks in different phases of equity crowdfunding

\begin{tabular}{|l|c|c|c|}
\hline & Pre-crowdfunding & Active crowdfunding & Post-crowdfunding \\
\hline Type of network ties & Strong ties & Weak ties & Strong ties \\
\hline $\begin{array}{l}\text { Relational Nature of } \\
\text { Network ties }\end{array}$ & Personal & Mostly business & Personal and business \\
\hline Duration of networks & Long term & Long, short term, ad hoc & Long and short term \\
\hline
\end{tabular}




\begin{tabular}{|c|c|c|c|}
\hline Role of network ties & $\begin{array}{l}\text {-Key role for strong ties } \\
\text { (friends, family and } \\
\text { existing network). } \\
\text {-Referral to CF platform } \\
\text { and strong influence on } \\
\text { where and how firms } \\
\text { engage in CF. } \\
\text {-Reliance on strong ties } \\
\text { to pre-seed CF round to } \\
\text { make CF viable. } \\
\text {-Strong interactions with } \\
\text { chosen platform }\end{array}$ & $\begin{array}{l}\text {-Continued support from } \\
\text { strong ties (friends, } \\
\text { family and existing } \\
\text { network). } \\
\text {-Active development of } \\
\text { new contacts (weak ties) } \\
\text { via interactions on } \\
\text { crowdfunding platforms. } \\
\text {-Engagement via social } \\
\text { media and other } \\
\text { interactions (e.g. } \\
\text { business plan requests). } \\
\text {-Transient interaction } \\
\text { crowd with the goal of } \\
\text { ultimately influencing } \\
\text { investment from angels } \\
\text { other professional } \\
\text { investors }\end{array}$ & $\begin{array}{l}\text {-Continued reliance on } \\
\text { strong ties (friends, } \\
\text { family and existing } \\
\text { network) for advice, } \\
\text { support and further } \\
\text { funding. } \\
\text {-Active conversion of } \\
\text { weak ties into strong ties. } \\
\text {-On-going engagement } \\
\text { and network } \\
\text { management no } \\
\text { strengthen } \\
\text { relationships. }\end{array}$ \\
\hline
\end{tabular}

Our first research question examined the role that different types of networks play in the equity crowdfunding process for start-ups. During this phase of the crowdfunding process - the precrowdfunding phase - personal networks dominated. Powerful network enablers strongly influenced and encouraged the entrepreneurs to pursue equity crowdfunding. Most of these were "strong ties", such as friends, family, current investors and peers. This "word of mouth" referral process seemed to be a key aspect of the crowdfunding process and interactions with strong ties within personal and professional networks often helped to allay any concerns. Indeed, network interactions between entrepreneurs and their peers are recognised to be a critical way to help entrepreneurs "handle such ambiguity" (Ciabuschi et al., 2012, p. 227). The pre-crowdfunding phase is perhaps the most crucial aspect of the equity crowdfunding process, as failure to properly engage with the right kind of networks can fatally undermine the success of a whole campaign.

Close ties also emerge between the platforms and the entrepreneurs, not least because of repeated interactions during the due diligence processes undertaken. Through this recursive process the entrepreneurs become passionate supporters of the platforms. Indeed, through this self-confirming and pro-social behaviour amongst crowdfunded entrepreneurs, many become advocates of the process who then to proceed to help other firms with their campaigns. Most of the entrepreneurs in 
our study had benefitted from discussions with other firms who had "been there, done that", providing further evidence of high levels of internal social capital within the crowdfunding "community" (Colombo et al., 2015) 7. It is important to note that as this study covered some of first cohorts of start-ups to use equity crowdfunding, so-called "early adopters" (Brown et al., 2015), similar findings may not be evident in future work on equity crowdfunding.

Spatial proximity also appears to play a key role in shaping pre-crowdfunding network interactions. These tended to take place either with personal networks or other start-ups, often via the conduit of incubator or accelerator programmes, which many of the firms inhabited. Close proximity and repeated exposure to crowdfunding platforms also seemed to foster network ties. As networking events by crowdfunding platforms tend to be organised in London, where the majority of platforms are located, it seems no coincidence that the vast majority of crowdfunding deals in our study and in other work (e.g. Baeck et al., 2014) are spatially proximate to London. The spatial boundedness circumscribing the main crowdfunding community in the UK corresponds closely to other forms of equity-based entrepreneurial finance (Martin et al., 2005; Mason \& Pierrakis, 2013). The contrasts with other findings (Agrawal et al., 2015) and suggests the "geography" of equity crowdfunding warrants further empirical research.

Network ties were also important for firms to "pre-seed" their crowdfunding campaigns. This preseeding, based on strong/known ties, gives new deals crucial momentum which then draws in other unknown investors (i.e. weak ties) and is closely associated with the success of crowdfunding campaigns (Colombo et al., 2015). Our findings also revealed that entrepreneurs leveraged established connections with business angels to help them to pre-seed and to raise finance via crowdfunding, demonstrating the importance of a signalling or herding detected by others examining equity crowdfunding (Ahlers et al, 2016; Kromidha and Robson, 2016). This form of

\footnotetext{
${ }^{7}$ In one instance, an entrepreneur who had successfully raised crowdfunding was contacted by half a dozen other firms in pursuit of his advice on how they could embark on a crowdfunding campaign.
} 
relational "piggybacking" of pre-existing strong ties emphasises a sense of "path dependence" (Hite, $2005)$ in the nature of network relationships in the crowdfunding process.

Our second research question examined how networks evolved over the crowdfunding process. In fact, the nature of network interactions and engagement differed quite markedly between the pre and active crowdfunding phases. The findings revealed that during the "active" phase of crowdfunding, business networks took centre stage. Whilst existing relationships and strong network ties were a critical part of the pre-crowdfunding phase, once a campaign went live, entrepreneurs focused less on their existing ties and more on engaging with new ties via the crowdfunding platform. This is perhaps unsurprising, given the nature and volume of information requests respondents received once their campaign went "live". Strong ties remained important, but more so for moral support rather than for strategic guidance. Via the crowdfunding platform, links to other entrepreneurs who had raised equity crowdfunding - as well as links directly to the wider crowd - become the focal point for entrepreneurs. These predominantly weak business network ties were considered crucial to enable the firms to successfully achieve their target funding. Social media was widely used, not only to engage with potential investors, but also to help build a sense of momentum for the campaign, which again is recognised to have an important effect on the "herding" behaviour of investors (Moritz et al., 2015; Ciuchta et al., 2016).

Upon completion of the crowdfunding campaign, the "relational mix" (Lechner et al., 2006) of ties changed once again. This reflects other work that emphasises the role of networks as flexible or "transient commitments" rather than inherently long-lasting relationships (Andersen \& Medlin, 2016). During this phase, the focus of entrepreneurs shifted to harnessing weak business network ties, particularly connections with new investors. At this juncture, previously weak ties, such as links to new investors (both large and small), begin to change and solidify. This occurred due to increased interactions between the firm and their new investors, drawing on new shareholders as sources of advice, co-creators of new knowledge, brand ambassadors and new customers. 
In sum, networks are of critical importance for the duration of the crowdfunding process, with each phase of the process focused on different aspects of network development and interaction (see Table 3). What seems to characterise this process is a transition away from personal strong ties, which in turn fosters engagement in wider business networks predicated on weak ties. In this research context, strong ties act as a conduit towards developing a range of weaker ties across a wider set of business networks. The desire to develop and "harden" these weak ties is perhaps the most fluid and dynamic aspect at the end of the crowdfunding process and requires further empirical scrutiny. The close interplay between different network relationships, both personal and business, validates the decision to take an integrative perspective within our empirical analysis.

\subsection{Relational Benefits arising from the crowdfunding process}

Our third research question sought to examine the impact from these evolving network interactions during the crowdfunding process for start-ups. It is quite clear that numerous relational and network benefits arose during the crowdfunding process from these entrepreneurial networks. The crowdfunding literature notes that crowdfundees derive various network benefits from the crowdfunding process; our empirical findings strongly corroborate this. One major benefit of crowdfunding for firms is the organisational legitimacy it confers on start-ups, which mitigates the liability of newness (Frydrych et al., 2014; Colombo et al, 2015). Given that platforms have to vet firms and undertake due diligence in advance of launching a campaign, a listing on a crowdfunding platform acts as a positive signal of legitimacy to potential investors. This is similar to the concept of "reputational networks" (Lechner \& Dowling, 2003) or "trust facilitation" (Hite, 2005) identified in the entrepreneurial networking literature. This results in increased visibility and heightened levels of trust for potential investors, a crucial benefit for informationally opaque new ventures (Welter \& Smallbone, 2006). This positive signalling connects ventures with a wide array of other potential investors, especially business angels. Indeed, many of the interviewees mentioned how the crowdfunding process had alerted other potential investors, many of whom were previously 
unknown to the entrepreneur. Being able to successfully raise crowdfunding could act as a "signal" of quality to uniformed third parties (Ahlers et al., 2015; Hsu, 2004), which in turn could further facilitate future investment.

In line with a range of other authors, the data also reveals considerable non-tangible benefits from interacting with crowd investors (Belleflamme et al., 2014; Lehner et al., 2015). We label these "more than money". These are often unanticipated outcomes, whereby entrepreneurs benefit by becoming better connected to customers and investors. Factors such as media exposure, interaction with new shareholders, end-user engagement and feedback were all important intangible networkrelated benefits that firms received from this type of funding. Indeed, investors in crowdfunding often become quite vocal and proactive in their engagement with these firms. In turn, entrepreneurs use these new networks to gain media exposure for their venture and to receive customer feedback on product development. ${ }^{8}$ Through these interactive feedback loops between entrepreneurs and investors, important entrepreneurial learning can occur (Belleflamme et al., 2014; Gerber \& Hui, 2013; Ordanini et al., 2011). Scholars claim that the ties between firms from different backgrounds can increase their ability to access a high volume and variety of information (Stam \& Elfring, 2008) or "network knowledge heterogeneity" (Sullivan \& Ford, 2014). The findings reported therefore corroborate that crowdfunding platforms are not only intermediaries of monetary transactions, but also important "loci of social connections" (Colombo et al., 2015, p. 76).

\section{Conclusions and Limitations}

\subsection{Contribution}

This paper presents rich and unique empirical insights into the role of networks in equity crowdfunding. Returning to the paper's overarching research question - what role do entrepreneurial networks play in the equity crowdfunding process - this paper makes two key contributions. First, our empirical findings demonstrate the important role that different types of

${ }^{8}$ One example of this was a UK microbrewery, which held a meeting of all their new investors in order to undertake tastings and ratings of their latest range of beers. 
networks - interpersonal and inter-organisational networks, strong and weak, close and far - play in mediating the equity crowdfunding process for start-ups. While crowdfunding networks help startups access funding, equally they stimulate and provide a conduit for wider boundary spanning interactions with a multiplicity of ties. These network effects mark equity crowdfunding out as a distinctively "relational" form of entrepreneurial finance, drawing heavily on both pre-existing and new ties on a variety of dimensions. The findings therefore call into question the view that internetmediated funding mechanisms are some kind of anonymised, transactional, spatially and socially disembedded forms of finance for start-ups (see Agrawal et al., 2015).

Second, this paper extends entrepreneurial network theories by adopting a dynamic processual perspective combining both $\mathrm{SN}$ and $\mathrm{BN}$ perspectives. How entrepreneurs manage these multiple and inter-related personal, professional and business networks is vital to understanding how equity crowdfunding operates. The adoption of this dynamic perspective undoubtedly aided our understanding of the complex temporal processes at play. Looking across the wider business ecosystem revealed that network connections to business incubators, accelerators, VCs, business angels, consultants, intermediaries and government were all shown to shape the crowdfunding process in its entirety. Static approaches that look at fixed sequences fail to capture this rapidly evolving transitive picture which start-ups face during this complex resource assembly process.

\subsection{Managerial Implications}

This study's findings also have important managerial implications. Given the funding difficulties facing start-ups, many entrepreneurs will have to become much more adept at leveraging this new forms of entrepreneurial finance. Utilising crowdfunding is significantly different from traditional forms of transactional debt finance. Entrepreneurs have to be much more outwardly focused and connected to a range of other network actors when trying to obtain this form of relational finance. In this environment, relational competency is now an important component of the financial literacy of these start-ups. The onus is also on managers to maximise the benefits from engaging with a 
wider array of existing and new network actors, so that these firms experience the relational spillovers outlined above. Utilising the pro-social behaviours of other entrepreneurs who have successfully gone through this process would seem an obvious way for capturing these kinds of learning experience.

As well as these opportunities, however, it is important to note that increased network interaction presents considerable managerial obstacles to most growing firms (Möller \& Halinen, 1999). Given that crowdfunding fosters a wide array of new stakeholders, it may in some cases distract - or indeed overwhelm - some start-ups as highlighted during our interviews. Managing these new stakeholder relationships and complex interdependencies, whilst avoiding managerial or "stakeholder overstretch", is critical if firms are to thrive in this environment. Therefore, orchestrating and maximising the benefits, both financial and relational, from equity crowdfunding requires significant levels of entrepreneurial orientation (Lumpkin \& Dess, 1996), which may be beyond the reach of less capable or indeed risk averse entrepreneurs.

\subsection{Limitations}

There are clear limitations associated with this empirical study. First, in common with the vast majority of studies examining networks a cross-sectional perspective was adopted (Greve \& Salaff, 2003; Sullivan \& Ford, 2014). Clearly, adding a time dimension would aid the richness to the findings. Researchers may wish to consider a real time "sequential mapping" method to capture the temporal dynamics more closely (Halinen et al., 2012). Second, as with other work on networking in nascent ventures it was biased towards successful firms (Sullivan \& Ford, 2014). It is important to note that only around $40 \%$ of firms successfully raise equity crowdfunding (Financial Times, 2015), so in some respects this is a biased sample of highly skilled and successful entrepreneurs. Further research might benefit from exploring the reasons why some firms fail to obtain it. One conjecture being that failure to obtain crowdfunding may correlate to having less developed or extensive network connections. Third, given the dominance of consumer-related firms in the sample, future work may 
wish to explore the dynamics of crowdfunding in high-tech sectors. These are just some suggestions for others to advance this fertile research agenda and we hope this encourages others to examine this rapidly moving "relational" form of entrepreneurial finance. 


\section{References}

Ahlers, G. K., Cumming, D., Günther, C., \& Schweizer, D. (2015). Signalling in equity crowdfunding. Entrepreneurship Theory and Practice 39 (955-980).

Aldrich, H., Rosen, B., \& Woodward, W. (1987). The impact of social networks on business foundings and profit: a longitudinal study. Frontiers of entrepreneurship research, 7(154), 68.

Agrawal, A., Catalini, C., \& Goldfarb, A. (2015). Crowdfunding: Geography, Social Networks, and the Timing of Investment Decisions. Journal of Economics \& Management Strategy, 24(2), 253-274.

Andersen, P. H., \& Medlin, C. J. (2016). Transient commitments and dynamic business networking. Industrial Marketing Management, 58, 11-19.

Baeck, P., Collins, L. and Zhang, B. (2014). Understanding Alternative Finance: The UK Alternative Finance Industry Report 2014, National Endowment for Science Technology \& Arts, Nesta.

Baraldi, E. (2008). Strategy in industrial networks: experiences from IKEA. California management review, 50(4), 99-126.

Belleflamme, P., Lambert, T., \& Schwienbacher, A. (2014). Crowdfunding: Tapping the right crowd. Journal of Business Venturing, 29(5), 585-609.

Bellavitis, C., Filatotchev, I., Kamuriwo, D. S., \& Vanacker, T. (2017). Entrepreneurial finance: new frontiers of research and practice, Venture Capital, 19(1-2), 1-16.

Berger, A. N., \& Udell, G. F. (1998). The economics of small business finance: The roles of private equity and debt markets in the financial growth cycle. Journal of banking \& finance, 22(6), 613-673.

Berger, A. N. \& Black, L.K. (2011). Bank size, lending technologies and small business finance. Journal of Banking and Finance, 35(3), 724-735.

Bhidé, A. V. (2003). The origin and evolution of new businesses. Oxford University Press, Oxford. 
Block, J. H., Colombo, M. G., Cumming, D. J., \& Vismara, S. (2017). New players in entrepreneurial finance and why they are there. Small Business Economics, 1-12.

Birley, S. (1986). The role of networks in the entrepreneurial process. Journal of business venturing, 1(1), 107-117.

British Business Bank. (2014). Equity Crowdfunding in the UK: Evidence from the Equity Tracker. Sheffield: British Business Bank. $\quad$ http://british-business-bank.co.uk/wpcontent/uploads/2015/03/230315-Equity-crowdfunding-report-final.pdf

Brown, R., Mawson, S., Rowe, A., \& Mason, C. (2015). Harnessing the Crowd: The Demand-Side Dynamics of Equity Crowdfunding in Nascent Entrepreneurial Ventures, Centre for Responsible Banking \& Finance, University of St Andrews WP 15-009. http://www.standrews.ac.uk/business/rbf/workingpapers/RBF15 009.pdf

Bruton, G., Khavul, S., Siegel, D., \& Wright, M. (2015). New Financial Alternatives in Seeding Entrepreneurship: Microfinance, Crowdfunding, and Peer-to-Peer Innovations. Entrepreneurship Theory and Practice, 39(1), 9-26.

Cassar, G. (2004). The financing of business start-ups. Journal of business venturing, 19(2), 261-283.

Ciabuschi, F., Perna, A., \& Snehota, I. (2012). Assembling resources when forming a new business. Journal of Business Research, 65(2), 220-229.

Ciuchta, M. P., Letwin, C., Stevenson, R. M., \& McMahon, S. R. (2016). Regulatory Focus and Information Cues in a Crowdfunding Context. Applied Psychology: An International Review, 65 (3), 490-514.

Colombo, M. G. \& Grilli, L. (2007). Funding gaps? Access to bank loans by high-tech start-ups. Small Business Economics, 29(1-2), 25-46.

Colombo, M. G., Franzoni, C., \& Rossi-Lamastra, C. (2015). Internal social capital and the attraction of early contributions in crowdfunding. Entrepreneurship Theory and Practice, 39(1), 75-100. 
Cordova, A. Dolci, J., \& Gianfrate, G. (2015) Crowdfunding: Toward the Democratization of Innovation Financing, In Archibugi, D., Filippetti, A., (Eds) "The Handbook of Global Science, Technology, and Innovation", John Wiley \& Sons, New York.

Cowling, M., Liu, W., \& Ledger, A. (2012). Small business financing in the UK before and during the current financial crisis. International Small Business Journal, 30(7), 778-800.

Cumming, D., \& Johan, S. (2013). Demand-driven securities regulation: Evidence from crowdfunding. Venture Capital, 15(4), 361-379.

Cumming, D. J., \& Vismara, S. (2017). De-segmenting research in entrepreneurial finance. Venture Capital, 19(1-2), 17-27.

Drover, W., Busenitz, L., Matusik, S., Townsend, D., Anglin, A., \& Dushnitsky, G. (2017). A Review and Road Map of Entrepreneurial Equity Financing Research: Venture Capital, Corporate Venture Capital, Angel Investment, Crowdfunding, and Accelerators. Journal of Management, doi/abs/10.1177/0149206317690584.

Dubois, A., \& Gadde, L. E. (2002). Systematic combining: an abductive approach to case research. Journal of Business Research, 55(7), 553-560.

Elfring, T., \& Hulsink, W. (2003). Networks in entrepreneurship: the case of high-technology firms. Small Business Economics, 21(4), 409-422.

Financial Times (2015). How growing businesses are playing to the crowd. London: Financial Times, 21/1/15

Freytag, P. V., \& Ritter, T. (2005). Dynamics of relationships and networks-creation, maintenance and destruction as managerial challenges. Industrial Marketing Management, 34(7), 644-647.

Frydrych, D., Bock, A. J., Kinder, T., \& Koeck, B. (2014). Exploring entrepreneurial legitimacy in reward-based crowdfunding. Venture Capital, 16(3), 247-269. 
Garnsey, E., Stam, E., \& Heffernan, P. (2006). New firm growth: Exploring processes and paths. Industry and Innovation, 13(1), 1-20.

Gedajlovic, E., Honig, B., Moore, C. B., Payne, G. T., \& Wright, M. (2013). Social capital and entrepreneurship: A schema and research agenda. Entrepreneurship Theory and Practice, 37(3), 455478.

Glückler, J. (2007). Economic geography and the evolution of networks. Journal of Economic Geography, 7(5), 619-634.

Graebner, M. E., Martin, J. A., \& Roundy, P. T. (2012). Qualitative data: Cooking without a recipe. Strategic Organization, 10(3), 276-284.

Granovetter, M. S. (1973). The strength of weak ties. American Journal of Sociology, 1360-1380.

Greiner,L. E. (1972). "Evolution and Revolution as Organisations Grow". Harvard Business Review, 50(4), 37-46.

Greve, A., \& Salaff, J. W. (2003). Social networks and entrepreneurship. Entrepreneurship Theory and Practice, 28(1), 1-22.

Guba, E. S. \& Lincoln, Y. S. (1994) Competing Paradigms in Qualitative Research, in Denzin, N. K. and Lincoln, Y. S. (eds.) Handbook of Qualitative Research, London, Sage, pp. 105-117.

Håkansson, H., Havila, V., \& Pedersen, A. C. (1999). Learning in networks. Industrial Marketing Management, 28(5), 443-452.

Håkansson, H., \& Snehota, I. (1989). No business is an island: the network concept of business strategy. Scandinavian Journal of Management, 5(3), 187-200.

Harrison, R. (2013). Crowdfunding and the revitalisation of the early stage risk capital market: catalyst or chimera?. Venture Capital, 15(4), 283-287. 
Healy, M. \& Perry, C. (2000) Comprehensive criteria to judge validity and reliability of qualitative research within the realism paradigm, Qualitative Market Research: An International Journal, 3(3), pp. $188-126$.

Hellmann, T., Lindsey, L., \& Puri, M. (2008). Building relationships early: Banks in venture capital. Review of Financial Studies, 21(2), 513-541.

Hite, J. M. (2005). Evolutionary processes and paths of relationally embedded network ties in emerging entrepreneurial firms. Entrepreneurship Theory and Practice, 29(1), 113-144.

Hoang, H., \& Antoncic, B. (2003). Network-based research in entrepreneurship: A critical review. Journal of Business Venturing, 18(2), 165-187.

Hsu, D. H. (2004). What do entrepreneurs pay for venture capital affiliation?. The Journal of Finance, 59(4), 1805-1844.

Katz, J., \& Gartner, W. B. (1988). Properties of emerging organizations. Academy of Management Review, 13(3), 429-441.

Kontinen, T., \& Ojala, A. (2011). Network ties in the international opportunity recognition of family SMEs. International Business Review, 20(4), 440-453.

Kromidha, E., \& Robson, P. (2016). Social identity and signalling success factors in online crowdfunding. Entrepreneurship \& Regional Development, 1-25.

Jack, S., Dodd, S. D., \& Anderson, A. R. (2008). Change and the development of entrepreneurial networks over time: a processual perspective. Entrepreneurship and Regional Development, 20(2), 125-159.

Johannisson, B., Ramírez-Pasillas, M., \& Karlsson, G. (2002). The institutional embeddedness of local inter-firm networks: a leverage for business creation. Entrepreneurship \& Regional Development, 14(4), 297-315. 
Lechner, C., \& Dowling, M. (2003). Firm networks: external relationships as sources for the growth and competitiveness of entrepreneurial firms. Entrepreneurship \& Regional Development, 15(1), 126.

Lechner, C., Dowling, M., \& Welpe, I. (2006). Firm networks and firm development: The role of the relational mix. Journal of Business Venturing, 21(4), 514-540.

Lee, N., \& Brown, R. (2016) Innovation, SMEs and the liability of distance: The demand and supply of bank funding in peripheral UK regions, Journal of Economic Geography, doi:10.1093/jeg/lbw011.

Leyden, D. P., Link, A. N., \& Siegel, D. S. (2014). A theoretical analysis of the role of social networks in entrepreneurship. Research Policy, 43(7), 1157-1163.

Löher, J. (2017). The interaction of equity crowdfunding platforms and ventures: an analysis of the preselection process. Venture Capital, 19(1-2), 51-74.

Lumpkin, G. T., \& Dess, G. G. (1996). Clarifying the entrepreneurial orientation construct and linking it to performance. Academy of Management Review, 21(1), 135-172.

Martin, R., Berndt, C., Klagge, B., \& Sunley, P. (2005). Spatial proximity effects and regional equity gaps in the venture capital market: evidence from Germany and the United Kingdom. Environment and Planning A, 37(7), 1207-1231.

Mason, C. M., \& Harrison, R. T. (1997). Business angel networks and the development of the informal venture capital market in the UK: Is there still a role for the public sector. Small Business Economics, 9(2), 111-123.

Mason, C., \& Stark, M. (2004). What do investors look for in a business plan? A comparison of the investment criteria of bankers, venture capitalists and business angels. International Small Business Journal, 22(3), 227-248.

Mason, C., \& Pierrakis, Y. (2013). Venture capital, the regions and public policy: the United Kingdom since the post-2000 technology crash. Regional Studies, 47(7), 1156-1171. 
Mattsson, L. G. (1997). "Relationship marketing" and the "markets-as-networks approach"-a comparative analysis of two evolving streams of research, Journal of Marketing Management, 13(5), 447-461.

Michel, S. (2001). "Analyzing Service Failures and Recoveries: A Process Approach". International Journal of Service Industry Management, 12(1), 20-33.

Mitchell, J. C. (Ed.). (1969). Social networks in urban situations: analyses of personal relationships in Central African towns. Manchester University Press, 1-50.

Möller, K. K., \& Halinen, A. (1999). Business relationships and networks: Managerial challenge of network era. Industrial Marketing Management, 28(5), 413-427.

Mollick, E. (2014). The dynamics of crowdfunding: An exploratory study. Journal of Business Venturing, 29(1), 1-16.

Moritz, A., Block, J., \& Lutz, E. (2015). Investor communication in equity-based crowdfunding: a qualitative-empirical study. Qualitative Research in Financial Markets, 7(3), 309-342.

Nesta (2016) Pushing Boundaries: The 2015 UK Alternative Finance Industry Report, National Endowment for Science, Technology and Arts.

OECD (2005). OECD SME and Entrepreneurship Outlook: 2005. Paris: OECD.

Ordanini, A., Miceli, L., Pizzetti, M., \& Parasuraman, A. (2011). Crowd-funding: transforming customers into investors through innovative service platforms, Journal of Service Management, 22(4), 443-470.

Patton, M. Q. (2002). Qualitative research and evaluation methods, Thousand Oaks, CA, Sage.

Ritter, T., Wilkinson, I. F., \& Johnston, W. J. (2004). Managing in complex business networks. Industrial Marketing Management, 33(3), 175-183. 
Saunders, M. N., \& Townsend, K. (2016). Reporting and Justifying the Number of Interview Participants in Organization and Workplace Research. British Journal of Management DOI: 10.1111/1467-8551.12182.

Seghers, A., Manigart, S., \& Vanacker, T. (2012). The impact of human and social capital on entrepreneurs' knowledge of finance alternatives. Journal of Small Business Management, 50(1), 6386.

Shane, S., \& Cable, D. (2002). Network ties, reputation, and the financing of new ventures. Management Science, 48(3), 364-381.

Simula, H., \& Ahola, T. (2014). A network perspective on idea and innovation crowdsourcing in industrial firms. Industrial Marketing Management, 43(3), 400-408.

Slotte-Kock, S., \& Coviello, N. (2010). Entrepreneurship research on network processes: a review and ways forward. Entrepreneurship Theory and Practice, 34(1), 31-57.

Smith, D. A., \& Lohrke, F. T. (2008). Entrepreneurial network development: Trusting in the process. Journal of Business Research, 61(4), 315-322.

Stam, W., \& Elfring, T. (2008). Entrepreneurial orientation and new venture performance: The moderating role of intra-and extraindustry social capital. Academy of Management Journal, 51(1), 97-111.

Street, C. T., \& Cameron, A. F. (2007). External relationships and the small business: A review of small business alliance and network research. Journal of Small Business Management, 45(2), 239-266.

Suddaby, R., Bruton, G. D., \& Si, S. X. (2015). Entrepreneurship through a qualitative lens: Insights on the construction and/or discovery of entrepreneurial opportunity. Journal of Business Venturing, 30(1), 1-10. 
Sullivan, D. M., \& Ford, C. M. (2014). How entrepreneurs use networks to address changing resource requirements during early venture development. Entrepreneurship Theory and Practice, 38(3), 551574.

Uzzi, B. (1999). Embeddedness in the making of financial capital: How social relations and networks benefit firms seeking financing. American sociological review, 481-505.

Uzzi, B., \& Gillespie, J. J. (2002). Knowledge spillover in corporate financing networks: Embeddedness and the firm's debt performance. Strategic Management Journal, 23(7), 595-618.

Uzzi, B., \& Lancaster, R. (2003). Relational embeddedness and learning: The case of bank loan managers and their clients. Management science, 49(4), 383-399.

Vismara, S. (2016). Equity retention and social network theory in equity crowdfunding. Small Business Economics, 46(4), 579-590.

Welter, F., \& Smallbone, D. (2006). Exploring the role of trust in entrepreneurial activity. Entrepreneurship Theory and Practice, 30(4), 465-475.

Witt, P. (2004). Entrepreneurs' networks and the success of start-ups. Entrepreneurship \& Regional Development, 16(5), 391-412.

Wright, M., Hart, M., \& Fu, K. (2015). A Nation of Angels: Assessing the impact of angel investing across the UK. Enterprise Research Centre. 